Provided for non-commercial research and education use. Not for reproduction, distribution or commercial use.

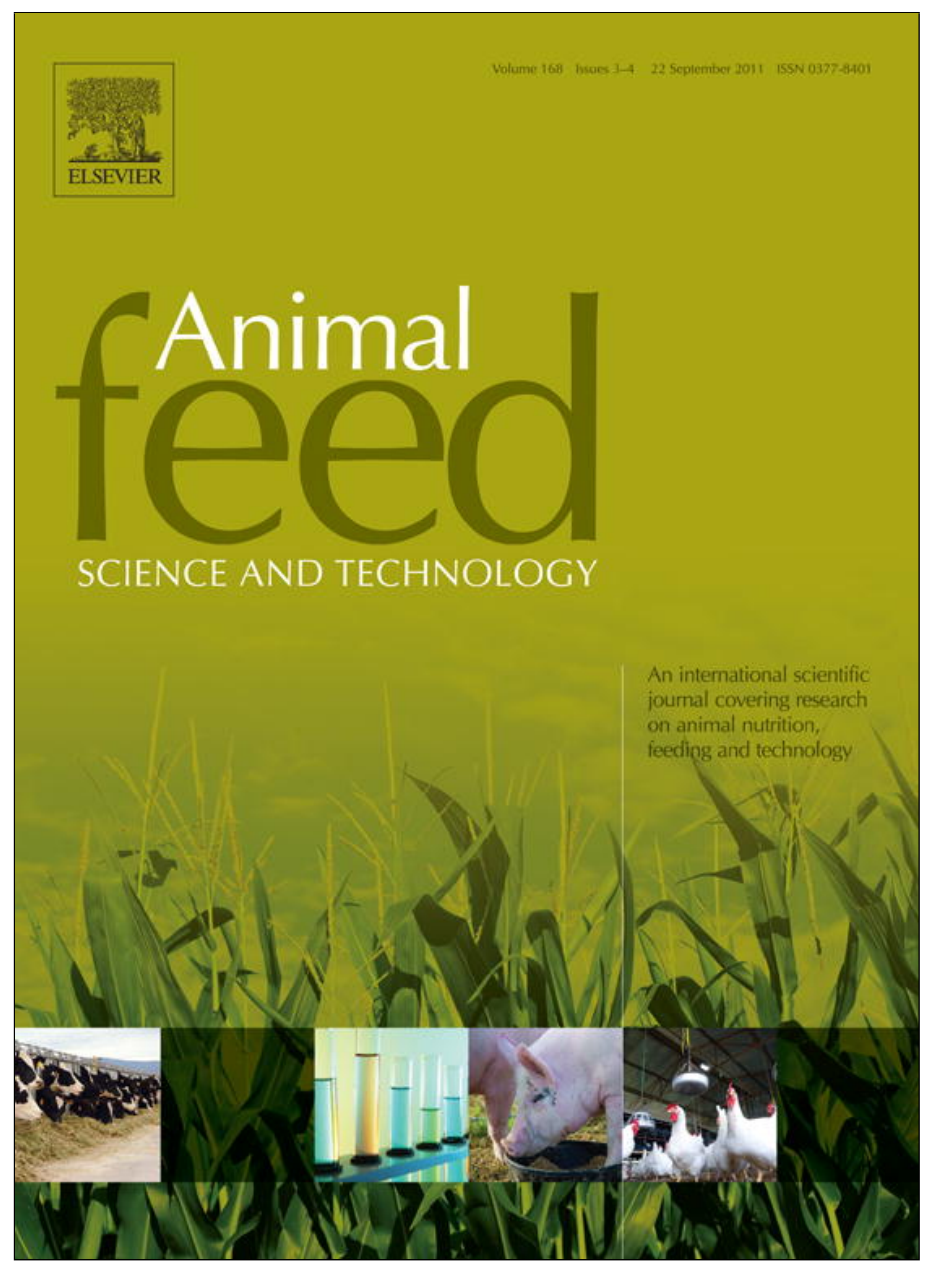

This article appeared in a journal published by Elsevier. The attached copy is furnished to the author for internal non-commercial research and education use, including for instruction at the authors institution and sharing with colleagues.

Other uses, including reproduction and distribution, or selling or licensing copies, or posting to personal, institutional or third party websites are prohibited.

In most cases authors are permitted to post their version of the article (e.g. in Word or Tex form) to their personal website or institutional repository. Authors requiring further information regarding Elsevier's archiving and manuscript policies are encouraged to visit:

http://www.elsevier.com/copyright 


\title{
A novel method to determine simultaneously methane production during in vitro gas production using fully automated equipment
}

\author{
W.F. Pellikaan ${ }^{a}$, W.H. Hendriks ${ }^{\text {a }}$ b , G. Uwimana ${ }^{\text {a }}$, L.J.G.M. Bongers ${ }^{a}$, P.M. Becker ${ }^{c}$, \\ J.W. Cone ${ }^{\mathrm{a}, *}$ \\ a Animal Nutrition Group, Department of Animal Sciences, Wageningen University, P.O. Box 338, NL-6700 AH Wageningen, The Netherlands \\ b Nutrition Division, Department of Farm Animal Health, Faculty of Veterinary Medicine, Utrecht University, Utrecht, The Netherlands \\ c Wageningen UR Livestock Research, P.O. Box 65, NL-8200 AB Lelystad, The Netherlands
}

\section{A R T I C L E I N F O}

\section{Article history:}

Received 29 November 2010

Received in revised form 11 April 2011

Accepted 29 April 2011

\section{Keywords:}

Additives

Gas production technique

Methane

Organic matter degradation

Rumen fermentation

\begin{abstract}
A B S T R A C T
An adaptation of fully automated gas production equipment was tested for its ability to simultaneously measure methane and total gas. The simultaneous measurement of gas production and gas composition was not possible using fully automated equipment, as the bottles should be kept closed during the incubations. A separate small opening with a screw cap and septum was made in each bottle, making it possible to take very small aliquots $(10 \mu \mathrm{l})$ from the gas in the headspace with a syringe for immediate gas analysis. As the used automatic gas production equipment was a venting system, corrections had to be made for the vented total gas and methane, as well as for the dilution of the produced methane with the gas in the headspace. To test the suitability and accuracy of the system, known amounts of methane were injected in bottles in the venting system and methane concentrations in the headspace were determined. It proved that the methane concentration in the headspace, corrected for the vented gas, coincided with the injected amount of methane. To show the potency of the adapted equipment, experiments were conducted with different feedstuffs. Total gas production and methane production were recorded and their relationships were calculated. The ability of the system to test feed additives for methane reduction was demonstrated for maize and soybean hulls as substrate ( $0.5 \mathrm{~g} \mathrm{DM})$, supplemented with monensin ( $15 \mathrm{mg}$ ), sodium-2-bromoethanesulphonate (BES, $15 \mathrm{mg}$ ), cinnemaldehyde $(150 \mathrm{mg})$ and tea tannins $(150 \mathrm{mg})$, additives known to effect methane synthesis. The adapted gas production equipment showed to be a powerful tool to determine rate and extent of gas production as a measure of fermentation and to simultaneously determine methane production.
\end{abstract}

(c) 2011 Elsevier B.V. All rights reserved.

\section{Introduction}

Methane is a strong greenhouse gas (Crutzen, 1995) with domestic ruminants being a major contributor to anthropogenic methane emissions. As such much research is currently conducted to minimize the methane synthesis during rumen fermentation (Newbold and Rode, 2006; Calsamiglia et al., 2007; Bodas et al., 2008; Eckard et al., 2010). Besides the contribution of methane to greenhouse gas emissions, methane synthesis in the rumen also represents a loss of dietary energy.

Abbreviations: ADFom, acid detergent fibre in the OM; BES, sodium-2-bromoethanesulphonate; Cfat, crude fat; CP, crude protein; DM, dry matter; NDF, neutral detergent fibre in the OM; OM, organic matter.

* Corresponding author. Tel.: +31 317483 542; fax: +31 317484260 .

E-mail address: john.cone@wur.nl (J.W. Cone). 
Methane emission from the rumen can be influenced by adaptation of the feeding regime, by feeding more fermentable starch (Ellis et al., 2008). However, this type of feeding strategies is only possible for high milk-producing cows with a high intake (Kirchkeßner et al., 1995). Animals, not producing milk cannot be fed high amounts of starch, as they become too fat, and alternatives should be found to decrease methane emissions by these animals. Much research is focused on the addition of oils (Alexander et al., 2008; Castillejos et al., 2008) and plant extracts (Benchaar et al., 2008; Bodas et al., 2008) to the daily ration of dairy cattle to reduce methane synthesis in the rumen and to alter biohydrogenation processes in the rumen (Durmic et al., 2008). Ideally, the additives should reduce the methane production, without interfering in the overall fermentation processes. However, many plant extracts also depress the overall fermentation of organic matter (OM) and volatile fatty acid (VFA) production. Bodas et al. (2008) reported that out of 450 investigated plant extracts, 35 decreased methane production by more than $15 \%$ and only 6 of that 35 showed no effect on overall fermentation.

Research on ways to reduce rumen methane synthesis should always be accompanied by determination of the total OM fermentation in order to maintain rumen functioning. Currently, the gas production technique (Menke et al., 1979) is widely used to study the rate and extent of organic matter fermentation in rumen fluid and fully automated systems are available (Pell and Schofield, 1993; Theodorou et al., 1994; Cone et al., 1996). Moreover, there is an increasing body of knowledge on the physiological background of the profiles (Cone et al., 1997; Cone and Van Gelder, 1999). The automated gas production equipment, as described by Cone et al. (1996) uses electric valves to vent the system, to prevent overpressure in the bottles and there is no possibility to analyze the composition of the vented gas. The gas production equipment, was adapted so that small quantities $(10 \mu \mathrm{l})$ of gas can be taken from the headspace, to be analyzed for methane concentration. The aim of this study was to investigate the possibilities of this adapted gas production system to accurately determine the kinetics of methane synthesis and to calculate the methane/total gas production ratio without disturbing the overall gas production measurements. To proof this, gas production and methane concentration in the produced gas was determined for different feedstuffs without and with some selected additives, known to influence methane production.

\section{Materials and methods}

\subsection{Gas production equipment and incubations}

An adapted version of the gas production equipment, as described by Cone et al. (1996), was used. The bottles were adapted and fitted with a glass extension and sealed with a screw cap and an air-tight septum (Fig. 1). Using a gas tight syringe (Hamilton 1701N, point style 5 needles, $51 \mathrm{~mm}$; Hamilton, Bonaduz, Switzerland) small aliquots of $10 \mu \mathrm{l}$ were sampled sequentially from the headspace gas and analyzed for methane.

Gas production incubations were performed as described by Cone et al. (1996). Rumen fluid was collected from two lactating rumen cannulated Holstein Friesian cows, $2 \mathrm{~h}$ after the morning feeding. Animal care was approved by an ethical committee and was done in accordance with Dutch legislation on the use of experimental animals. The cows received grass and maize silage in the morning and afternoon and $7-8 \mathrm{~kg}$ of concentrate $(160 \mathrm{~g} / \mathrm{kg} \mathrm{DM} \mathrm{starch,300} \mathrm{g/kg} \mathrm{CP,} 38 \mathrm{~g} / \mathrm{kg}$ DM Cfat and $80 \mathrm{~g} / \mathrm{kg}$ DM ash) according to their requirements. Rumen fluid from both cows was combined and stored in warm insulated flasks filled with $\mathrm{CO}_{2}$, filtered through two layers of cheesecloth, and mixed $(1: 2$, v/v) with an anaerobic buffer/mineral solution as described by Cone et al. (1996). Samples (0.5 g DM) were incubated in duplicate in $60 \mathrm{ml}$ buffered rumen fluid in $250 \mathrm{ml}$ bottles in a shaking water bath at $39^{\circ} \mathrm{C}$ and gas production was recorded for $72 \mathrm{~h}$. Each experiment was done in a separate single run. All manipulations were under continuous flushing with $\mathrm{CO}_{2}$. Gas production measurements were corrected for blank gas productions (i.e., gas productions in buffered rumen fluid without sample).

\subsection{Testing the system for methane measurements}

The bottles ( $250 \mathrm{ml}$ serum bottles, Schott, Mainz, Germany) had a total volume up to the upper edge of $300 \mathrm{ml}$. With the added $60 \mathrm{ml}$ buffered rumen fluid, the gas headspace was $240 \mathrm{ml}$. At the start of the incubations, the headspace in the bottles was filled with $\mathrm{CO}_{2}$. During rumen fermentation incubations, gas (mainly $\mathrm{CO}_{2}$ and $\mathrm{CH}_{4}$ ) is produced and mixed with the gas in the headspace. At the same time when gas is produced, the system is vented and the same amount of gas is released. Therefore, the methane concentration in the headspace is a mixture of the original $\mathrm{CO}_{2}$ present in the headspace and produced fermentation gas, minus the vented gas. As such there is an indirect relationship between the analyzed methane concentration in the headspace and the amount of methane synthesized during fermentation. The latter can be calculated from the methane concentration in the headspace, the amount of gas vented and the concentration of methane in the escaped gas. To check the accuracy of the determination of methane production, a bottle with $60 \mathrm{ml}$ buffer in a water bath of $39{ }^{\circ} \mathrm{C}$ was filled with pure $\mathrm{CO}_{2}$ and 10 times $10 \mathrm{ml}$ of pure methane (Matheson Tri-Gas, Twinsburg, OH, USA) was injected via a syringe through a special tap fitted on the screw cap. The injection of $10 \mathrm{ml}$ of methane resulted in the venting of $10 \mathrm{ml}$ of gas from the headspace by the venting system. After the methane injection, $10 \mu$ l of the gas in the headspace was obtained via the glass capped extension using a gas tight syringe and analyzed for methane. The whole procedure of 10 injections with $10 \mathrm{ml}$ of methane was repeated 5 times after which the entire procedure was repeated again 5 times with injections of $10 \mathrm{ml}$ of methane followed by $40 \mathrm{ml}$ of $\mathrm{CO}_{2}$. 


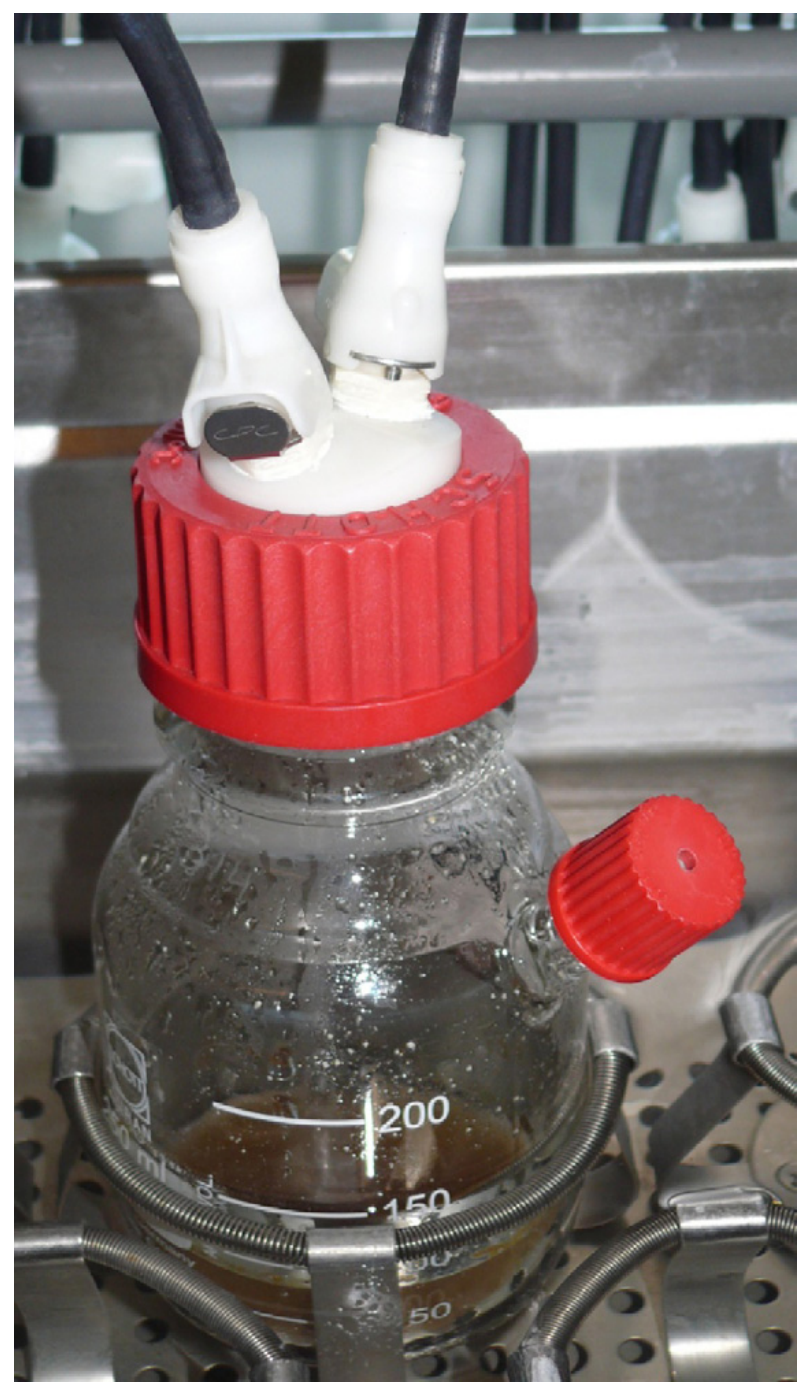

Fig. 1. Bottle used for gas production measurements adapted for sampling $10 \mu \mathrm{l}$ of the headspace for gas analysis.

\subsection{Feedstuffs and chemical analysis}

Feed ingredients of different origin and with different chemical compositions (Table 1 ) were ground to pass a $1 \mathrm{~mm}$ screen. The contents of DM and ash were determined gravimetrically after $4 \mathrm{~h}$ at $103^{\circ} \mathrm{C}$ (ISO 6496) and $550{ }^{\circ} \mathrm{C}$ (ISO 5984 ), respectively.

Table 1

Dry matter (DM, g/kg) and chemical composition $(\mathrm{g} / \mathrm{kg} \mathrm{DM})$ of the investigated feed samples.

\begin{tabular}{|c|c|c|c|c|c|c|c|c|c|}
\hline \multirow[t]{2}{*}{ Feedstuffs } & \multirow{2}{*}{$\begin{array}{l}\mathrm{DM} \\
\mathrm{g} / \mathrm{kg}\end{array}$} & Ash & $\mathrm{CPa}^{\mathrm{a}}$ & $\mathrm{Cfat}^{\mathrm{b}}$ & NDFom $^{c}$ & ADFom $^{d}$ & $\operatorname{Lignin}(\mathrm{sa})^{\mathrm{e}}$ & Starch & Sugars \\
\hline & & \multicolumn{8}{|c|}{$\mathrm{g} / \mathrm{kg} \mathrm{DM}$} \\
\hline Maize & 893 & 14 & 99 & 41 & 82 & 27 & 1 & 738 & 22 \\
\hline Potato starch, native & 893 & 15 & 0 & 17 & 25 & 17 & 5 & 787 & 28 \\
\hline Soybean hulls & 895 & 49 & 112 & 15 & 648 & 470 & 13 & 7 & 17 \\
\hline Beet pulp & 917 & 79 & 88 & 14 & 356 & 182 & 8 & 4 & 234 \\
\hline Grass silage & 945 & 96 & 198 & 47 & 458 & 267 & 19 & 0 & 66 \\
\hline Maize silage & 960 & 73 & 74 & 31 & 401 & 222 & 20 & 323 & 12 \\
\hline Linseed expeller & 924 & 60 & 373 & 97 & 205 & 129 & 44 & 24 & 53 \\
\hline Palm kernel expeller & 915 & 48 & 158 & 93 & 590 & 366 & 98 & 1 & 21 \\
\hline Sainfoin & 909 & 48 & 213 & - & - & - & - & - & - \\
\hline Lucerne hay & 913 & 101 & 211 & - & - & - & - & - & - \\
\hline Brewers grain & 919 & 46 & 267 & 98 & 534 & 194 & 30 & 24 & 3 \\
\hline
\end{tabular}

a $\mathrm{CP}$ : crude protein.

b Cfat: crude fat.

c NDFom: neutral detergent fibre.

d ADFom: acid detergent fibre.

e Lignin(sa): acid detergent lignin. 
Starch content was determined after a pre-extraction with ethanol (316 g/l) as glucose using the amyloglucosidase method (Keppler and Decker, 1970) after autoclaving the starch for $2 \mathrm{~h}$ at $120^{\circ} \mathrm{C}$. Nitrogen (N) was determined using the Kjeldahl method (ISO 5983) and crude protein (CP) was calculated as $6.25 \mathrm{~N}$. Crude fat (Cfat) was determined gravimetrically after $6 \mathrm{~h}$ extraction with petroleum-ether (ISO 6492). Sugars were measured colorimetrically, as described by Van Vuuren et al. (1993), after extraction with $40 \%$ ethanol followed by a treatment with $0.023 \mathrm{M} \mathrm{HCl}$ to hydrolyse the bonds between sugar molecules. Neutral detergent fibre (NDFom), acid detergent fibre (ADFom) and lignin (sa) were determined by the detergent procedures of Van Soest et al. (1991) and Robertson and Van Soest (1981). NDFom was determined without the use of sodium sulphite and amylase. NDFom and ADFom were expressed without residual ash.

Methane was determined using a gas chromatograph (GC8000Top, CE Instruments, Milan, Italy) fitted to a flame ionization detector, using a packed column (PorapakQ, $6 \mathrm{~m} \times 1 / 8 \mathrm{in}$., 50-80 mesh, Grace/Alltech, Lexington, Kentucky, USA) with nitrogen as carrier gas $(100 \mathrm{kPa})$ and an oven temperature maintained at $60^{\circ} \mathrm{C}$.

\subsection{Incubations to determine gas production and methane}

In the first experiment, $0.5 \mathrm{~g}$ of different feed samples (Table 1 ) was incubated in duplicate using the adapted gas production technique. Also a blank (buffered rumen fluid without sample) was incubated in duplicate and used to correct the gas production of the samples. Gas production was recorded automatically, as described by Cone et al. (1996). At 0, 2, 4, 6, 8, 10, $12,24,30,36,48$ and $72 \mathrm{~h}$, an aliquot of $10 \mu \mathrm{l}$ of the gas in the headspace of each bottle was taken by the gas tight syringe and the methane concentration was immediately determined by gas chromatography. The methane concentrations were plotted against time and a modified nonlinear monophasic sigmoidal model (Groot et al., 1996) was fitted through the data points. Curve fit parameters describing the increasing methane concentrations in time, were then used to compute methane concentrations at each individual valve opening. Cumulative methane production was calculated out of the methane concentration in the headspace and corrected for the amount of methane vented from the bottle, and expressed as ml methane per gram of incubated OM.

In a second experiment, duplicate incubations of $0.5 \mathrm{~g}$ maize and soybean hulls were conducted with different amounts of additives reported to inhibit methane synthesis: sodium-2-bromoethanesulphonate (BES, $15 \mathrm{mg} / 0.5 \mathrm{~g}$ OM incubated, Sigma-Aldrich, St. Louis, MO, USA), monensin sodium salt (15 mg/0.5 g OM, Sigma-Aldrich, St. Louis, MO, USA), cinnemaldehyde (150 mg/0.5 g OM) and tea tannins (150 mg/0.5 g OM). Cinnemaldehyde (cinnamon oil powder) was provided by Orffa Additives B.V., Werkendam, The Netherlands. Green tea tannins (Tannino TVR, 84.9\%) were provided by Silva Group, San Michele Mondovi (CN), Italy. As the aim of this paper was to investigate the possibilities to use the adapted gas production technique to determine total gas production and methane simultaneously and to use this technique to study the influences of feedstuffs and additives on both total gas production and methane, relatively high amounts of additives were used to be sure that methane synthesis was influenced. It was not the aim of this paper to study the influence of the additives, nor its concentrations.

\subsection{Statistical analysis}

Effects of additive on substrate fermentation characteristics were tested by analyzes of variance using the GLM procedure of SAS (2003) as:

$$
Y_{i j k}=\mu+S_{i}+A_{j}+(S * A)_{i j}+\varepsilon_{i j k}
$$

where, $Y_{i j k}$ is the dependent variable, $\mu$ the overall mean, $S_{i}$ is the substrate type $(i=2), A_{j}$ represents the effect of additive treatment $(j=5),\left(S^{*} A\right)_{i j}$ is the interaction term and $\varepsilon_{i j k}$ is the error term. Differences between the main effects were analyzed using Tukey-Kramer's multiple comparison procedure in the LSMEANS statement in SAS, with effects considered significant at a probability value of $\mathrm{P}<0.05$.

\section{Results}

\subsection{Procedure to determine methane synthesis}

The methane concentration in a bottle was measured in the gas in the headspace after each injection of $10 \mathrm{ml}$ of pure methane and after each injection of $10 \mathrm{ml}$ of methane followed by $40 \mathrm{ml}$ of $\mathrm{CO}_{2}$ (Fig. 2). The amount of injected methane, simulating methane synthesis during fermentation, was calculated out of the determined methane concentration in the headspace and the cumulative amount of escaped gas and its composition. The calculated cumulative amount of methane out of the determined concentrations in the headspace is shown in Fig. 2 (closed symbols), and coincided with the injected total amount of methane. 


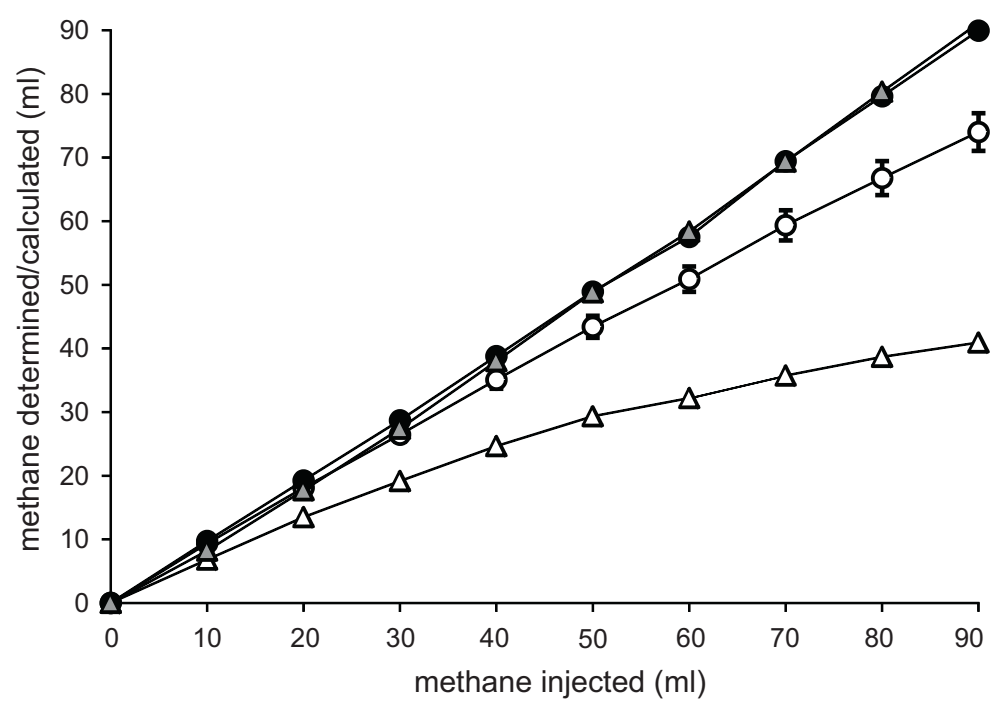

Fig. 2. Amounts of $10 \mathrm{ml}$ of methane $(0)$ or $10 \mathrm{ml}$ of methane followed by $40 \mathrm{ml}$ of air $(\Delta)$ were injected in the headspace ( $240 \mathrm{ml})$ of a bottle, previously filled with $\mathrm{CO}_{2}$, after which the methane concentration was determined in the headspace and the volume of methane in the headspace was calculated. As the used gas production technique is a venting one, the determined volume of methane is less than the injected amount of methane. By taking account of the composition of the vented gas and the dilution with the headspace, the amount of injected methane could be calculated out of the determined concentration of methane $(\bullet)$ injections of $10 \mathrm{ml}$ each; $(\boldsymbol{\Delta})$ injections of $10 \mathrm{ml}$ methane and $40 \mathrm{ml}$ air each.

\subsection{Incubation of different feedstuffs}

The chemical composition of the incubated feedstuffs is shown in Table 1. The feedstuffs showed large variation in chemical composition and especially in CP, NDFom, starch and sugar content. Table 2 shows the maximum gas production, maximum calculated methane production and calculated methane fraction in the total produced gas. Gas production was highest for potato starch and lowest for brewers grains. Also methane synthesis showed a large variation, with the highest methane synthesis obtained for potato starch and the lowest for linseed expeller and palm kernel expeller. The fraction of methane in the total amount of synthesized gas varied from 0.127 for maize to 0.211 for brewers grain.

\subsection{Effect of additives}

Samples of $0.5 \mathrm{~g}$ maize and soybean hulls were incubated and were supplemented with monensin, BES, cinnamaldehyde or tea tannins. Figs. 3 and 4 show the gas production profiles of soybean hulls and maize with and without the additives. BES at $15 \mathrm{mg} / 0.5 \mathrm{~g}$ did not have a large influence on the total gas production of the soybean hulls (Fig. 3 ), whereas the other additives influenced the gas production profiles for soybean hulls. The effects of the additives on the total gas production of maize (Fig. 4) were much less pronounced than for soybean hulls (Fig. 3).

\section{Table 2}

Total gas production and methane produced after $72 \mathrm{~h}$ incubation of selected samples in buffered rumen fluid and the calculated fraction of methane in the total amount of gas produced.

\begin{tabular}{llll}
\hline Feedstuffs & $\begin{array}{l}\text { Total gas } \\
\text { ml/g OM }\end{array}$ & $\begin{array}{l}\text { Total } \mathrm{CH}_{4}{ }^{\mathrm{a}} \\
\mathrm{ml} / \mathrm{g} \mathrm{OM}\end{array}$ \\
\hline Maize & 361.3 & 43.4 & 0.127 \\
Potato starch, native & 399.9 & 66.8 & 0.167 \\
Soybean hulls & 367.1 & 62.3 & 0.170 \\
Beet pulp & 354.2 & 60.8 & 0.172 \\
Grass silage & 273.3 & 47.6 & 0.174 \\
Maize silage & 318.6 & 55.8 & 0.175 \\
Linseed expeller & 217.8 & 38.5 & 0.177 \\
Palm kernel expeller & 221.7 & 38.9 & 0.180 \\
Sainfoin & 246.1 & 46.1 & 0.187 \\
Luzern meal & 273.4 & 53.5 & 0.196 \\
Brewers grain & 191.6 & 40.3 & 0.211 \\
SEM & 4.77 & 2.46 & 0.0142 \\
LSD & 27.28 & 14.05 & 0.0813 \\
P-value (feedstuff) & $<.0001$ & $<.0001$ \\
\hline
\end{tabular}

\footnotetext{
a $\mathrm{CH}_{4}$ : methane.
}

b SEM: standard error of the mean.

c Least square difference. 


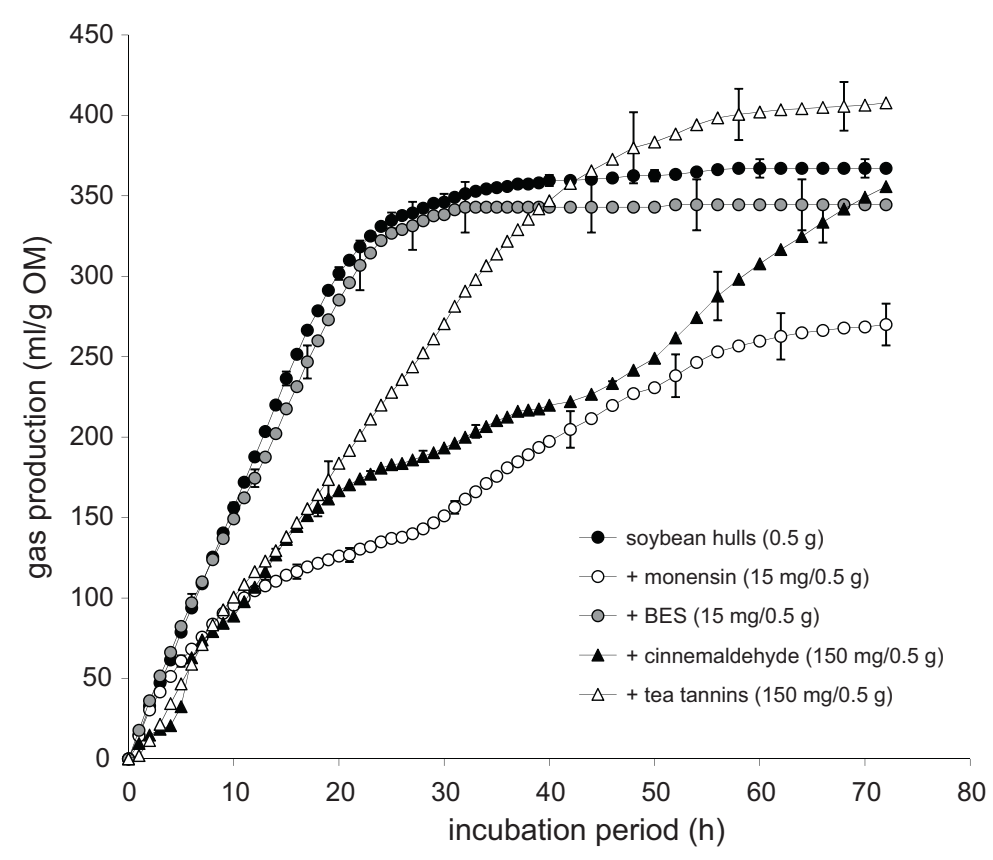

Fig. 3. Gas production profiles of a sample soybean hulls with different additives (dose $/ 0.5 \mathrm{~g}$ of soybean hulls). BES= sodium-2-bromoethanesulphonate.

Simultaneously with the gas production the concentration of methane in the headspace was analyzed. The methane synthesis during the fermentation of the soybean hulls is shown in Fig. 5. All additives influenced the methane production. During the initial $30 \mathrm{~h}$ of the incubation, no methane was produced with the additives BES and cinnamaldehyde. After $30 \mathrm{~h}$, methane production started. Maximum gas production and maximum methane production are shown in Table 3, as well as the calculated fraction of methane in the total gas produced. Upon incubation of the sample soybean hulls, without additives, the fraction of methane was 0.170 . All additives reduced the methane fraction in the total gas, with the lowest values recorded with the addition of BES (0.010), cinnamaldehyde (0.061) and monensin (0.078).

The methane synthesis during the fermentation of the maize sample is shown in Fig. 6. The addition of BES and cinnamaldehyde resulted in no production of methane. Also the other additives, monensin and tea tannins, showed a considerable effect on methane production during fermentation. The results in Table 3 show that all additives reduced the fraction of methane in the total gas.

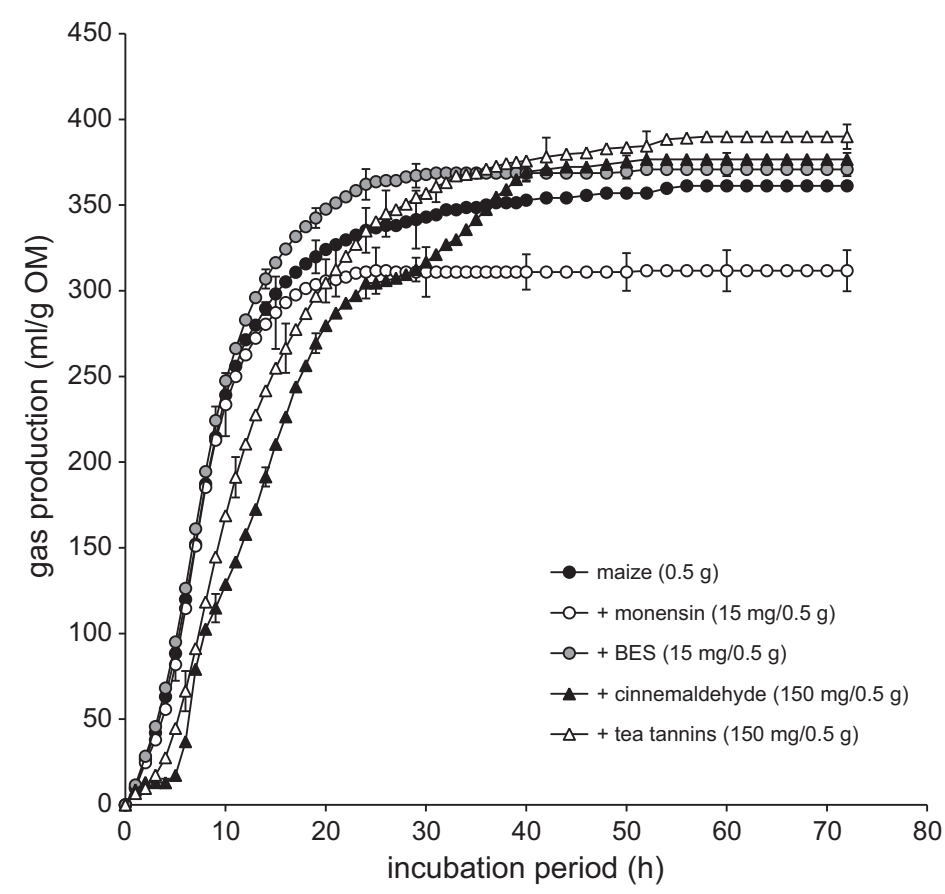

Fig. 4. Gas production profiles of a sample maize with different additives (dose $/ 0.5 \mathrm{~g}$ of maize). BES= sodium-2-bromoethanesulphonate. 


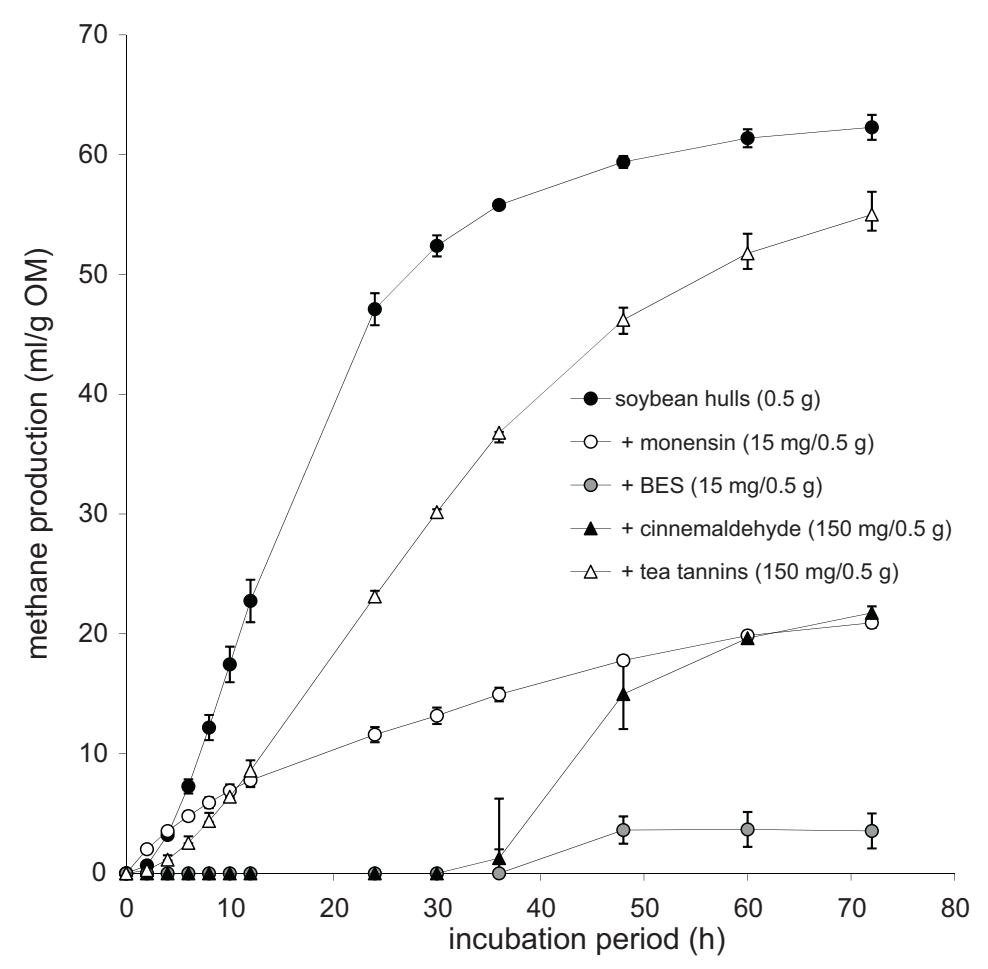

Fig. 5. Methane $\left(\mathrm{CH}_{4}\right)$ production profiles of a sample soybean hulls with different additives (dose/0.5 g of soybean hulls). BES=sodium-2bromoethanesulphonate.

Table 3

Total gas production and methane produced after $72 \mathrm{~h}$ incubation of soybean hulls and maize in buffered rumen fluid with different additives and the calculated fraction of methane in the total amount of gas produced.

\begin{tabular}{|c|c|c|c|c|}
\hline Sample + additive & $\begin{array}{l}\text { Additive } \\
\mathrm{mg}\end{array}$ & $\begin{array}{l}\text { Total gas } \\
\mathrm{ml} / \mathrm{g} \text { OM }\end{array}$ & $\begin{array}{l}\text { Total } \mathrm{CH}_{4}{ }^{\mathrm{a}} \\
\mathrm{ml} / \mathrm{g} \mathrm{OM}\end{array}$ & $\mathrm{CH}_{4} /$ gas \\
\hline Soybean hulls & 0 & $367^{a}$ & $62.3^{\mathrm{a}}$ & $0.170^{\mathrm{a}}$ \\
\hline+ monensin & 15 & $270^{c}$ & $20.9^{b}$ & $0.078^{\mathrm{b}}$ \\
\hline$+\mathrm{BES}^{\mathrm{b}}$ & 15 & $344^{\mathrm{b}}$ & $3.5^{\mathrm{c}}$ & $0.010^{\mathrm{d}}$ \\
\hline +cinnamaldehyde & 150 & $356^{\mathrm{ab}}$ & $21.7^{\mathrm{b}}$ & $0.061^{c}$ \\
\hline +tea tannins & 150 & $408^{d}$ & $55.0^{\mathrm{a}}$ & $0.135^{\mathrm{b}}$ \\
\hline Maize & 0 & $340^{\mathrm{a}}$ & $43.4^{\mathrm{a}}$ & $0.127^{a}$ \\
\hline+ monensin & 15 & $312^{\mathrm{c}}$ & $18.8^{\mathrm{b}}$ & $0.060^{\mathrm{b}}$ \\
\hline$+\mathrm{BES}$ & 15 & $371^{\mathrm{b}}$ & $0^{c}$ & $0^{c}$ \\
\hline +cinnamaldehyde & 150 & $377^{\mathrm{ab}}$ & $0^{c}$ & $0^{c}$ \\
\hline +tea tannins & 150 & $390^{d}$ & $27.3^{\mathrm{b}}$ & $0.070^{\mathrm{b}}$ \\
\hline SEM & & 3.5 & 1.96 & 0.0036 \\
\hline P-value (additive) & & $<0.0001$ & $<0.0001$ & $<0.0001$ \\
\hline
\end{tabular}

a: $\mathrm{CH}_{4}$ : methane; b: BES: sodium-2-bromoethanesulphonate; superscripts within a column for each substrate indicated a significant (P<0.05)effect of the additive compared with the substrate without additive.

\section{Discussion}

Research on the effects of additives on methane emission should always be accompanied by determination of the OM fermentation, or by indirect determination of the OM fermentation, provided by the gas production technique (Menke et al., 1979; Menke and Steingass, 1988). Different substances have been shown to inhibit methane production from rumen fermentation (Alexander et al., 2008; Bodas et al., 2008; Calsamiglia et al., 2007; Grainger et al., 2009). However, when this is accompanied by a simultaneous inhibition of the overall fermentation in the rumen, addition of such a substance, although highly effective, is not efficient. An additive should fully inhibit methane production and have no influence on OM fermentation (Bodas et al., 2008). Generally research on methane synthesis and OM fermentation determine methane after a fixed incubation period (Alexander et al., 2008; Bodas et al., 2008), providing little information on kinetics of methane synthesis in vitro. The standard automated venting gas production technique, as developed by Cone et al. (1996), is not suitable for the determination of the rate and extent of methane synthesis during in vitro fermentation and was therefore adapted.

Table 2 shows that there were differences in total gas production, methane production and the fraction of methane in the total synthesized gas between the various feedstuffs investigated. The methane fraction varied from 0.170 in soybean hulls 


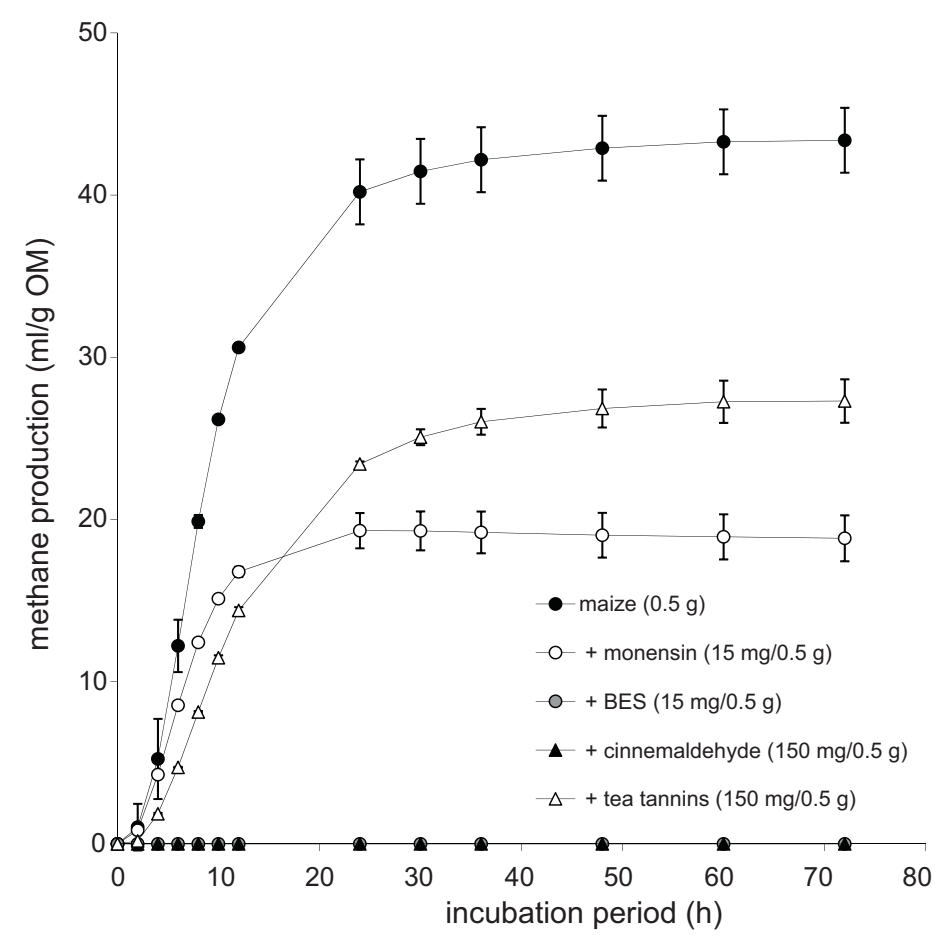

Fig. 6. Methane $\left(\mathrm{CH}_{4}\right)$ production profiles of a sample maize with different additives (dose $/ 0.5 \mathrm{~g}$ of maize). BES=sodium-2-bromoethanesulphonate.

to 0.211 in brewers grains and were of the same order of magnitude as shown by Bodas et al. (2008), who used the same buffer/mineral solution (Menke and Steingass, 1988). This is the fraction of the total gas production, as observed in vitro. The gas production technique (Menke et al., 1979) is based on the principle of releasing direct gas caused by the fermentation and releasing indirect gas because of a shift in the carbonate buffer by the synthesis of volatile fatty acids. So, the fraction of methane of the total gas production does not have to be exactly the same as observed in vivo in the animal, as the buffer composition in the rumen can be different from that in vitro (Counotte et al., 1979; Menke et al., 1979). However, for the screening of samples and additives for methane production in relation to total gas production, which is a measure for OM fermentation, this does not matter.

The experiments using methane inhibiting additives clearly show that all additives had an effect on the rate and extent of total gas production of the soybean hulls. The gas production curve with BES came close to that of soybean hulls without supplement (Fig. 3), although the final gas production was lower with BES (Table 3). The additives monensin, cinnamaldehyde and tea tannins decreased the rate of gas production. Part of this decreased rate of fermentation, measured as total gas production, can be attributed to lowered methane production which is part of total gas production, with strongest effect over the complete time period for monensin, BES and cinnamaldehyde. However, the final gas production came close to that of the soybean hulls without additives, with the exception of monensin (Fig. 3). Addition of monensin causes a shift in the microbial population towards gram negative bacteria, shifting the fermentation from acetic acid into propionic acid (Moss et al., 2000). Monensin can have a major effect on methane synthesis (Demeyer and Fievez, 2000), with this effect being larger for rations with roughage than concentrate (Baker, 1999). Moreover, the effect of monensin might be non-persistent (Carmean and Johnson, 1990; Moss et al., 2000). The final gas production of soybean hulls with added tea tannins was higher than without addition. This might have been caused by (partial) fermentation of the added substance, as 150 mg of tea tannins was added to $500 \mathrm{mg}$ substrate. These altered gas production profiles (Fig. 3) with additions might also indicate a process of adaptation. During the initial hours of fermentation microbial activity is inhibited, but after a prolonged incubation period, all the substrate is fermented. Animut et al. (2008) observed a decreased methane emission in sheep fed a ration supplemented with different condensed tannin sources. This was also observed by Grainger et al. (2009), but with a simultaneous reduction in intake and milk yield. Also the methane production after $30 \mathrm{~h}$ of incubation of the soybean hull sample with added cinnamaldehyde and BES, may be indicative of changes in the rumen micro flora. A potential mechanism could be explained by increased synthesis of propionic acid or lower formation of [H] due to reduced production of acetic acid (Busquet et al., 2005). BES inhibit methane synthesis by selectively interfering with co-enzyme M (Immig et al., 1996), while the precise mechanism of action of cinnamaldehyde is unknown (Calsamiglia et al., 2007). Also Moss et al. (2000) showed that halogenated compounds reduce methane synthesis for a limited period and possibly methanogenic bacteria can adapt to BES in the rumen (Immig et al., 1996). Based on the results in the present study (Figs. 2 and 3 and Table 3 ), BES showed only a limited influence on the total gas production and an almost complete inhibition of the methane synthesis. However, little can be said about the prolonged use (several weeks or months) of this additive in vivo, as the used in vitro system is a batch system, without the possibility of prolonged adaptation of the rumen micro flora. 
The total gas production of maize (Fig. 4) did shows a much less pronounced effect of the additives compared to the fermentation of the soybean hulls (Fig. 3). The fermentation of the maize sample up to $15 \mathrm{~h}$ was not influenced by the addition of monensin and BES. The addition of cinnamaldehyde and tea tannins resulted in a slight decrease in total gas produced up to $15 \mathrm{~h}$. This difference in effect of the additives between soybean hulls and maize may have been caused by the difference in chemical composition of the two samples. The major component of maize is starch $(738 \mathrm{~g} / \mathrm{kg})$ and of soybean hulls NDFom (648 g/kg) (Table 1). Starch and NDF are degraded in the rumen by different groups of micro organisms, which might show different susceptibilities to the additives, as shown by Baker (1999) for monensin. Upon the fermentation of the maize samples, cinnamaldehyde and BES showed a complete inhibition of methane synthesis. Monensin and tea tannins showed only a partial inhibition of the methane synthesis (Fig. 6 and Table 3). Cinnamaldehyde and BES showed no negative effect of the total gas production and a complete inhibition of methane synthesis. Again, the real effect of these additives upon prolonged use in vivo needs to be investigated. Additionally it could be argued that lower fermentation rates of starch, may lead to increased levels of rumen bypass starch, which could be used as glucogenic energy source in the small intestine.

The results show that the adapted gas production equipment is suitable to measure the rate and extent of total gas production and simultaneously the rate and extent of methane synthesis. Whereas other reports used a fixed incubation period to study methane inhibition (Alexander et al., 2008; Bodas et al., 2008), with the technique presented here, it is possible to investigate changes and adaptations during the incubation. One of the disadvantages of in vitro techniques is that no effects of prolonged addition on methane synthesis can be determined. However, the adapted gas production technique reported here offers the possibility to screen relatively large numbers of samples and additives for methane synthesis in a fast and economical way. Observing methane inhibition in vitro does not necessarily mean that the effects will also be seen upon prolonged use in the animals. On the other hand, when no inhibiting effect is seen in vitro, it is very unlikely that inhibiting effect will be seen in vivo and as such the adapted in vitro system reported here can be useful for the development of feeding regimes or feed additive to reduce methane emission by ruminants.

\section{Conclusions}

The adapted gas production equipment offers the possibility to determine total gas production, as a measure of OM fermentation, and methane synthesis simultaneously. With this system the maximum level of total gas production and methane synthesis can be determined, as well as the kinetics of synthesis. With this technique a fast screening of feedstuffs and additives for methane synthesis and total gas production is possible.

\section{References}

Alexander, G., Singh, B., Sahoo, A., Bhat, T.K., 2008. In vitro screening of plant extracts to enhance the efficiency of utilization of energy and nitrogen in ruminant diets. Anim. Feed Sci. Technol. 145, 229-244.

Animut, G., Puchala, R., Goetsch, A.L., Patra, A.K., Sahlu, T., Varel, V.H., Wells, J., 2008. Methane emission by goats consuming different sources of condensed tannins. Anim. Feed Sci. Technol. 144, 228-241.

Baker, S.K., 1999. Biology of rumen methanogens, and stimulation of animal immunity. In: Ryenga, P.J., Howden, S.M. (Eds.), Meeting the Kyoto Target Implications for the Australian Livestock Industries. Workshop Proceedings, Canberra, November 4-5, Bureau of Rural Sciences, Canberra. pp. 41-49.

Benchaar, C., Calsamiglia, S., Chaves, A.V., Fraser, G.R., Colombatto, D., McAllister, T.A., Beauchemin, K.A., 2008. A review of plant-derived essential oils in ruminant nutrition and production. Anim. Feed Sci. Technol. 145, 209-228.

Bodas, R., López, S., Fernández, M., Carcia-González, R., Rodríguez, A.B., Wallace, R.J., González, J.S., 2008. In vitro screening of the potential of numerous plant species as antimethanogenic feed additives for ruminants. Anim. Feed Sci. Technol. 145, 245-258.

Busquet, M., Calsamiglia, S., Ferret, A., Cardozo, P.W., Kamel, C., 2005. Effects of cinnamaldehyde and garlic oil on rumen microbial fermentation in a dual flow continuous culture. J. Dairy Sci. 88, 2508-2516.

Calsamiglia, S., Busquet, M., Cardozo, P.W., Castillejos, L., Ferret, A., 2007. Invited review: essential oils as modifiers of rumen microbial fermentation. J. Dairy Sci. 90, 2580-2595.

Carmean, B.R., Johnson, D.E., 1990. Persistence of monensin-induced changes in methane emissions and ruminal protozoa numbers in cattle. J. Anim. Sci. 65 (Suppl. 1), S 517.

Castillejos, L., Calsamiglia, S., Martín-Tereso, J., Ter Wijlen, H., 2008. In vitro evaluation of effects of ten essential oils at three doses on ruminal fermentation of high concentrate feedlot-type diets. Anim. Feed Sci. Technol. 145, 259-270.

Cone, J.W., Van Gelder, A.H., 1999. Influence of protein fermentation on gas production profiles. Anim. Feed Sci. Technol. 76, $251-264$.

Cone, J.W., Van Gelder, A.H., Driehuis, F., 1997. Description of gas production profiles with a three-phasic model. Anim. Feed Sci. Technol. $66,31-45$.

Cone, J.W., Van Gelder, A.H., Visscher, G.J.W., Oudshoorn, L., 1996. Influence of rumen fluid and substrate concentration on fermentation kinetics measured with a fully automated time related gas production apparatus. Anim. Feed Sci. Technol. 61, 113-128.

Counotte, G.H.M., Van 't Klooster, A.T., Van der Kuilen, J., Prins, R.A., 1979. An analysis of the buffer system in the rumen of dairy cattle. J. Anim. Sci. 49, $1536-1544$.

Crutzen, P.J., 1995. The role of methane in atmospheric chemistry and climate. In: von Engelhardt, W., Leonhard-Marek, S., Breves, G., Giesecke, D. (Eds.), Ruminant Physiology: Digestion, Metabolism, Growth and Reproduction. Ferdinand Enke Verlag, Stuttgart, Germany, pp. $291-315$.

Demeyer, D., Fievez, V., 2000. Ruminants et environnement: la méthanogenèse. Ann. Zootech. 49, 95-112.

Durmic, Z., McSweeney, C.S., Kemp, G.W., Hutton, P., Wallace, R.J., Vercoe, P.E., 2008. Australian plants with potential to inhibit bacteria and processes involved in ruminal biohydrogenation of fatty acids. Anim. Feed Sci. Technol. 145, 271-284.

Eckard, R.J., Grainger, C., De Klein, C.A.M., 2010. Options for the abatement of methane and nitrous oxide from ruminant production: a review. Livest. Sci. $130,47-56$.

Ellis, J.L., Dijkstra, J., Kebreab, E., Bannink, A., Odongo, N.E., McBride, B.W., France, J., 2008. Aspects of rumen microbiology central to mechanistic modelling of methane production in cattle. J. Agric. Sci. 146, 213-233.

Grainger, C., Clarke, T., Auldist, M.J., Beauchemin, K.A., McGinn, S.M., Waghorn, G.C., Eckard, R.J., 2009. Potential use of Acacia mearnsii condensed tannins to reduce methane emissions and nitrogen excretion from grazing dairy cows. Can. J. Anim. Sci. 89, $241-251$.

Groot, J.C.J., Cone, J.W., Williams, B.A., Debersaque, F., Lantinga, E.A., 1996. Multiphasic analysis of gas production kinetics on in vitro ruminal fermentation. Anim. Feed Sci. Technol. 64, 77-89. 
Immig, I., Demeyer, D., Fiedler, D., Van Nevel, C., Mbanzamihigo, L., 1996. Attempts to induce reductive acetogenesis into a sheep rumen. Arch. Anim. Nutr. 49, 363-370.

Kirchkeßner, M., Windisch, W., Müller, H.L., 1995. Nutritional factors for the quantification of methane production. In: Engelhart, W., von, Leonhard-Marek, S., Breves, G., Giesecke, D. (Eds.), Ruminant Physiology: Digestion, Metabolism, Growth and Reproduction. Ferdinand Enke Verlag, Stuttgart, Germany, pp. 333-348.

Keppler, D., Decker, K., 1970. Glykogen bestimmung mit amyloglucosidase. In: Bergmeyer, H.U. (Ed.), Methoden der Enzymatischen Analysen, Vol. , 2nd ed. Verlag Chemie, Weinheim, pp. 1089-1099.

Menke, K.H., Raab, L., Salewski, A., Steingass, H., Fritz, D., Schneider, W., 1979. The estimation of the digestibility and metabolizable energy content of ruminant feedingstuffs from gas production when they are incubated with rumen liquor in vitro. J. Agric. Sci. 93, $217-222$.

Menke, K.H., Steingass, H., 1988. Estimation of the energetic feed value obtained from chemical analysis and in vitro gas production using rumen fluid. Anim. Res. Dev. 28, 7-55.

Moss, A.R., Jouany, J.P., Newbold, J., 2000. Methane production by ruminants: its contribution to global warming. Ann. Zootech. 49, 231-253.

Newbold, C.J., Rode, L.M., 2006. Dietary additives to control methanogenis in the rumen. Int. Congr. Ser. 1293, $138-147$.

Pell, A.N., Schofield, P., 1993. Computerized monitoring of gas production to measure forage digestion in vitro. J. Dairy Sci. 76, $1063-1073$.

Robertson, J.B., Van Soest, P.J., 1981. The detergent system of analysis and its application in human foods. In: James, W.P.T., Theander, O. (Eds.), The Analysis of Dietary Fiber in Food. Marcell Dekker Inc., New York, NY, USA, pp. 123-158.

SAS, 2003. SAS User's Guide: Statistics, Version 9.1.3. SAS Institute, Cary, NC, USA.

Theodorou, M.K., Williams, B.A., Dhanoa, M.S., McAllan, A.B., France, J., 1994. A new gas production method using a pressure transducer to determine the fermentation kinetics of ruminant feeds. Anim. Feed Sci. Technol. 48, 185-197.

Van Soest, P.J., Robertson, J.B., Lewis, B.A., 1991. Methods for dietary fiber, neutral detergent fiber and non-starch polysaccharides in relation to animal nutrition. J. Dairy Sci. 74, 3583-3597.

Van Vuuren, A.M., Van der Koelen, C.J., Valk, H., De Visser, H., 1993. Effects of partial replacement of ryegrass by low protein feeds on rumen fermentation and nitrogen loss by dairy cows. J. Dairy Sci. 76, 2982-2993. 